\title{
APLIKASI UNTUK MENGUBAH NOT ANGKA MENJADI NOT BALOK DALAM PARTITUR DISERTAI FITUR 'MEDIA PLAYER'
}

\author{
${ }^{1)}$ Sani Handika Lubis, ${ }^{2)}$ Sidik Rahmatullah \\ ${ }^{3)}$ Ahmad Fikri Habibillah \\ Dosen Tetap Sistem Informasi, STMIK Dian Cipta Cendikia Lampung \\ Email : akukamukita88@yahoo.com
}

\begin{abstract}
ABSTRAK
Aplikasi untuk mengubah not angka menjadi not balok dalam partitur disertai fitur 'media player' ini menyoroti konversi not dengan cara yang mudah. Program aplikasi ini mendapatkan inputan berupa not angka. Inputan ini akan diproses menjadi not balok beserta tanda-tandanya. Proses transposisi dilakukan dengan cara mengubah not angka menjadi not balok berdasarkan tangga nada do $=C$. Proses transposisi ini dilakukan satu-persatu untuk setiap not angka, sehingga pada akhirnya seluruh not angka berhasil dirubah menjadi not balok. Dalam proses transposisi ini tanda awal dan tanda accidental perlu mendapat perhatian, karena baik tanda awal maupun tanda accidental akan sangat mempengaruhi hasil transposisi. Setelah proses transposisi selesai, maka akan didapatkan not balok beserta tanda-tandanya yang merupakan hasil konversi dari not angka yang diinputkan. Pada program aplikasi ini juga terdapat fasilitas untuk mendengarkan bunyi nada dari not balok yang dihasilkan. Metode waterfall digunakan dalam pengembangan aplikasi ini. Aplikasi ini menggunakan bahasa pemrograman Borland Delphi 7.0 dan Microsoft Access sebagai database.
\end{abstract}

Kata kunci : konversi not angka, aplikasi, media player, borland delphi 7.0 